Meta

Journal des traducteurs

Translators' Journal

\title{
Academic Writing and Culture: An Overview of Differences between English, French and German
}

\section{Dirk Siepmann}

Volume 51, numéro 1, mars 2006

URI : https://id.erudit.org/iderudit/012998ar

DOI : https://doi.org/10.7202/012998ar

Aller au sommaire du numéro

Éditeur(s)

Les Presses de l'Université de Montréal

ISSN

0026-0452 (imprimé)

1492-1421 (numérique)

Découvrir la revue

Citer cet article

Siepmann, D. (2006). Academic Writing and Culture: An Overview of Differences between English, French and German. Meta, 51(1), 131-150. https://doi.org/10.7202/012998ar
Résumé de l'article

Le présent article propose une vue d'ensemble critique des acquisitions récentes de la recherche sur les divergences culturelles en matière de prose scientifique, tout en illustrant les apports de cette recherche à la traductologie. D’abord, on étudie la notion de « style intellectuel " proposé par Galtung ainsi que les rapports entre enseignement de la rédaction et techniques d'écriture. Ensuite on passe en revue un certain nombre d'études contrastives consacrées à différents types de texte et qui mettent en évidence de nets décalages entre les pratiques d'écriture observables dans les communautés linguistiques anglophones, francophones et germanophones. Cette pluralité des pratiques d'écriture, conclut-on, doit être préservée comme une valeur en soi, et elle appelle une attention particulière de la part du traducteur. 


\title{
Academic Writing and Culture: An Overview of Differences between English, French and German
}

\author{
DIRK SIEPMANN \\ Siegen University, Siegen, Germany \\ dsiepmann@t-online.de
}

\begin{abstract}
RÉSUMÉ
Le présent article propose une vue d'ensemble critique des acquisitions récentes de la recherche sur les divergences culturelles en matière de prose scientifique, tout en illustrant les apports de cette recherche à la traductologie. D'abord, on étudie la notion de «style intellectuel» proposé par Galtung ainsi que les rapports entre enseignement de la rédaction et techniques d'écriture. Ensuite on passe en revue un certain nombre d'études contrastives consacrées à différents types de texte et qui mettent en évidence de nets décalages entre les pratiques d'écriture observables dans les communautés linguistiques anglophones, francophones et germanophones. Cette pluralité des pratiques d'écriture, conclut-on, doit être préservée comme une valeur en soi, et elle appelle une attention particulière de la part du traducteur.
\end{abstract}

\section{ABSTRACT}

This article provides a critical overview of recent research on cross-cultural divergences between English, French and German academic writing, demonstrating its relevance to translation. The author starts by discussing Galtung's notion of culture-specific intellectual styles. He then explores the relationship between composition teaching and writing style. This is followed by a detailed discussion of cross-language comparisons of various text types which lend evidence to significant differences between the linguacultures under survey. The resultant plurality of linguacultures, the author goes on to argue, must be preserved as a value in itself, and merits special attention on the part of the translator.

\section{MOTS-CLÉS/KEYWORDS}

academic writing, cross-language comparison, culture-specific intellectual styles, writing styles

Unter Südländern ist die Sprache ein Ingredienz der Lebensfreude, dem man weit lebhaftere gesellschaftliche Schätzung entgegenbringt, als der Norden sie kennt. Es sind vorbildliche Ehren, in denen das nationale Bindemittel der Muttersprache bei diesen Völkern steht, und etwas heiter Vorbildliches hat die genußreiche Ehrfurcht, mit der man ihre Formen und Lautgesetze betreut. Man spricht mit Vergnügen, man hört mit Vergnügen - und man hört mit Urteil [... $]^{1}$

THOMAS MANN, MARIO UND DER ZAUBERER

\section{Introduction}

For a long time the idea has been around that the 'spirit' of a language exerts a formative influence on its speakers and writers. First voiced explicitly by German philosopher Karl Wilhelm von Humboldt as far back as the early nineteenth century, it may be seen as a natural extrapolation of the view that, as the Count de Buffon had it, 'le style est l'homme même' (Dournon 1994: 394). There is, accordingly, a long tradition 
of investigating lexico-syntactic difference between languages, a tradition which can be traced back to such $19^{\text {th }}$ century comparative philologists as Friedrich von Schlegel, Franz Bopp and the Brothers Grimm.

Cross-cultural difference in thought and writing patterns, on the other hand, has become a serious field of enquiry only in the last twenty years or so. Two opposing positions have emerged, one stressing the universality of academic discourse (Widdowson 1979, Schwanzer 1981), the other postulating the culture-specificity of cognitive and textual structures (e.g. Kaplan 1966/1980, Clyne 1981, 1987, Galtung 1985, House 1997, Kachru 1983). I take issue with the first position here, thus favouring the second.

Universalists such as Widdowson (1979: $51 \mathrm{ff}$.) start from the assumption that, since scientists all over the world use the same concepts and procedures in their work, science constitutes a 'secondary cultural system' which is detached from the primary linguacultures. As a result, he argues,

the discourse conventions which are used to communicate this common culture are independent of the particular linguistic means which are used to realize them

There is little quarrel with the general premise here, yet Widdowson's status as an ESL specialist with, perhaps, little knowledge of foreign languages as well as his overreliance on 'hard' science texts may have led him to jump to a somewhat incautious conclusion. While there are good reasons for positing syntactic and stylistic universals characteristic of scientific discourse - such as passive constructions or nominalisation - such an analysis is far too superficial. A moment's reflection suggests that general cross-linguistic constants of this kind exist in any sub-language. Thus, parodying Widdowson's line of argument, we might say that turn-taking, hesitation and imprecision are universal features of colloquial speech.

In fairness to Widdowson, however, it must be pointed out that, when setting up his thesis, he probably had in mind only exact sciences such as physics or chemistry, where there is indeed a greater degree of rigidity in discourse conventions, especially as far as textual macrostructure is concerned. However, other disciplines claiming science status, such as social psychology (see Hutz 1997) or sports science (see Trumpp 1998), have remained averse to abandoning culture-specific patterns. It will come as no surprise, then, that Widdowson's thesis has been challenged and, at least to some extent, disproved by a number of later studies. These show that classification by academic disciplines and text types yields a more subtly differentiated picture of cross-cultural difference.

The present article looks at some of the major relevant studies, moving from general assumptions about culture-specific thinking styles (Section 2) to the more specific issues of academic writing (Sections 3 and 4). The concluding sections 5 and 6 discuss issues surrounding the preservation or abandonment of the current plurality of academic cultures and their implications for composition and translation teaching.

\section{Intellectual Styles}

In a wide-ranging speculative sweep Galtung (1985) suggested four metaphors to capture divergences in intellectual style between four broadly-conceived academic communities: the 'Saxon', the 'Teutonic', the 'Gallic' and the 'Nipponic'. He correlates these styles of sociological thought and writing in terms of criteria such as academics' ability to analyse paradigms, to generate hypotheses (or 'propositions'), to form theo- 
ries, to describe parameters and to comment on the work of others. Here is a thumbnail sketch of the conclusions he draws for the languages engaging our attention:

- The Saxonic intellectual style, which can be further subdivided into a US and a UK style, is characterized by avid collection and organisation of data in what is often a team effort. Accordingly, it is strong on hypothesis generation, but weak on theory formation. Moreover, Saxonic academics actively engage in dialogue with their peers, seek to smooth out divergences of opinion and are generally more tolerant of diversity. The typical questions posed by the Saxonic when confronted with a thesis are: 'How do you operationalize it?' (US version) and 'How do you document it?' (UK version).

- Gallic intellectual style is seen as being preoccupied with linguistic artistry. Clarity and elegance of style are as important as theory formation, and the best theory is one which shows balance and symmetry. Criticism of peers is concealed behind the smoke screen of language. The typical research question is: 'Peut-on dire cela en bon français?' ('Can you say this in good French?')

- Teutonic intellectual style focuses on fundamental issues of theory formation and deductive reasoning rather than data analysis and induction. The Teutonic intellectual community is less democratic and strongly elitist, with academic knowledge passing from 'masters' to 'apprentices'. Academic debate centres around the weaknesses of others' lines of argument. The typical research question is: 'Wie können Sie das ableiten?' ('How can you derive this?')

Informal support for Galtung's observations, which were not entirely original at the time he made them, may be derived from the writings of novelists and journalists. As for French intellectual style, compare the epigraph inscribed on the first page of this study, in which Thomas Mann, writing in the 1920s, reverently describes the 'appreciation and awe' with which language is treated in Southern European countries - hence the above-cited question 'Peut-on dire cela en bon français?' and ministerial statements such as 'The quality of our language also contributes to the quality of our lives' ('La qualité de la langue contribue, elle aussi, [...] à la qualité de la vie', Chirac 1975). The disciplined essay style resulting from such attitudes, to be described below, is satirized as being outmoded by German lecturer and journalist Karl Heinz Götze (1993: 87-97). All this testifies to the great relevance of aesthetic concerns to linguistic sentiment in France and other Southern countries.

\section{Education Systems and Writing Styles}

It is not difficult to relate the cultural differences perceived by Galtung to the education systems of each culture. In France mastery of the generally accepted essay technique is of greatest importance, permitting, as it does, to obtain highly coveted posts in academia and administration. At all levels, whether it be the baccalaureate, ${ }^{2}$ the CAPES or the agrégation, a successful conclusion of the course requires the writing of an essay in the time-honoured way traceable to the precepts of Scholastic Dialectic (cf. Götze 1993: 92). A typical essay question in French literature asks students to comment on a quotation from a renowned author who features among the set works; witness the following example:

Ionesco writes in Notes et Contre-notes: 'Comedy is comic only if it is a little frightening' Say whether this statement reflects your idea of comedy, drawing on your experience of the theatre and the cinema, but also taking into consideration the comedians whose sketches you know. ${ }^{3}$ (my translation) 
Philosophical subjects are usually phrased as straightforward questions, such as ' $\mathrm{Y}$ a-t-il un sens à parler de pratiques contre nature au sujet de l'homme?' (Does it make sense to speak of unnatural practices in the case of humans?, Boillot 1994: 48) or 'En quoi le langage est-il spécifiquement humain' ('In what sense is language specifically human?', Boillot 1994: 79). The examinee has to treat such questions with ordered precision and analytic rigour, paying equal attention to all possible aspects of the problem in hand. The essay follows a clear progression: having pinpointed the problem and defined any ambiguous notions, the examinee proceeds to give an explanatory summary of the way in which she intends to solve the problem. This outline must be strictly observed in the body of the essay. The latter consists of three or four evenlysized parts, which in turn fall into paragraphs of similar length. Each paragraph develops one argument; arguments are arranged in logical succession from the simple to the complex. Transitions between paragraphs are provided by bridge sentences which take up the thread of the argument. In the conclusion, the examinee presents her solution and may then take a brief look at the wider implications of the problem under discussion.

Linguistically, the essay must not violate the rules of the bon français, the scholarly written standard prescribed by the Académie française $e^{4}$ which, largely unchanged since the $17^{\text {th }}$ century, has drawn its authority from the judgements of the 'best' authors. Further, it must show rigid adherence to the time-endorsed technical terms compiled in specialized vocabulary books. Nowhere is there such an abundance of style and other language guides as in France; and nowhere does there seem to be such ironclad agreement on what constitutes good style.

To turn now to Britain, Hermanns (1985) notes that British students of language and literature are required to write one or two essays of no less than 3000 words each week. The finished products are read out aloud in one-to-one tutorials, with the tutor asking questions and offering comments. It is only logical, then, that reader orientation and essay form should be of utmost importance to Anglo-Saxon academic culture: a paragraph should normally open with a topic sentence, which all other sentences in the paragraph must support. A concluding sentence helps to end one paragraph and to provide a smooth transition to the next (cf. e.g. Byleen 1998: 10). Of equal importance is a strong focus on the assigned topic (cf. e.g. Holten/Marasco 1998: 230); digression and repetition are regarded as major vices. These features of higher education in English-speaking countries clearly lay the foundation for the tolerant Saxonic intellectual style described by Galtung, as well as for the reader-oriented Saxonic writing style to be discussed below.

In marked contrast to their English and French counterparts, German students have until recently received no principled instruction in composition in either secondary or higher education, and their university courses do not normally include faceto-face reading and discussion of essays. As a rule, students write their essays in isolation; professors or their assistants then read their finished products, mark them and attach some written comment. Through exposure to the publications of acknowledged scholars students are assumed to pick up automatically, as it were, the complex features of German academic register, where citations from secondary literature are generally more important than in the Anglo-Saxon and French academic cultures. As a result, the focus in German academic writing is on subject-matter knowledge and content rather than form or style, and there is a greater tolerance of digression. 


\section{Empirical Studies of Communicative Styles}

In a more serious vein, a vast array of studies lends empirical support to Galtung's thesis (see Section 2 above). From a series of investigations into pragmatic difference between German and English conversation (House 1979, 1982a, 1982b, 1982c, 1989a, 1989b, 1996) a clear pattern emerges:

German subjects tended to interact in ways that were more direct, more explicit, more self-referenced and more content-oriented. German speakers were also found to be less prone to resort to using verbal routines than English speakers. (House 1997: 84)

The greater degree of self-reference observed by House links up with Galtung's thesis that German-educated scholars are not very fond of team work and tend to focus on the weaknesses of others; the greater content orientation of Germans may be related to Galtung's typical research question 'Wie können Sie das ableiten?'

The growing body of literature on cross-cultural communication provides further evidence for Galtung's distinctions. Writing on cultural differences in the world of work, Hofstede $(1984 ; 1991)$ comes up with four dimensions along which cultures differ: individualism/collectivism, power distance, uncertainty avoidance and masculinity/femininity. It is evident that cultural divergences along these dimensions may also make themselves felt in academia and may therefore impact on styles of academic writing, to which we now turn.

There are a number of studies lending credence to the assumption that cultures differ with regard to their writing styles. In his seminal paper Kaplan (1966/1980) observed differences in paragraph structure between non-native and native English writing. Having compared a large number of translations from various languages as well as English-language compositions produced by natives of different countries, he postulated five types of paragraph movement in English, Russian, Semitic, Oriental and Romance languages. In regard to English paragraph development he observed that the thought patterns which readers of English appear to expect are 'dominantly linear'; while paragraph development may be discursive, it is never digressive (Kaplan 1966/1980: 402-403). By contrast, French paragraph writing is found to be much more tolerant of digression.

Clyne's $(1987,1991)$ work on cultural differences in discourse patterns is narrower in scope but more focussed than Kaplan's. Drawing on a substantial corpus of linguistic and sociological texts written by English and German speakers, Clyne brings into higher relief the extent to which German and English academic texts differ in linearity or digressiveness. Each text is subjected to a complex analysis within four parameters:

- Hierarchy of text: Which macropropositions are dependent on which others? [...]

- Dynamics of text: How is the text developed in terms of a main argument and subsidiary arguments? [...]

- Symmetry: How long are the various sections of the text in comparison?

- Uniformity: Are parallel text segments [... structured in the same order or according to the same conventions? (Clyne 1987: 218)

The following is a sketch of the principal results of Clyne's studies.

Firstly, and most importantly, he finds that texts by German-educated speakers show a greater degree of digressiveness, which can be ascribed to two major causes. 
One cause lies in the German tendency to stray from the main line of argument in a lengthy 'Exkurs', a category for which English 'has neither a conceptual [...] nor a translation equivalent' (Clyne 1987: 214). In other words, digression often has a welldefined function in German academia: to provide theory, historical background or additional information, to qualify preceding statements or to 'enter into polemic with another author' (Clyne 1987: 227). The second cause is that texts may simply not be well-planned, there being, for example, a mismatch between theoretical and empirical sections.

By the same token, German texts are seen to be more assymetrical on two counts: textual assymetry ('some sections of the paper are much longer than others') and propositional assymetry ('imbalance in the length of related propositions branching from the same macroproposition'). It is easy to see that both these findings link up with the aforementioned focus on content rather than form prevalent in German writing.

Another finding is the relative paucity of advance organizers in texts by German academics. Germans tend to place advance organizers in somewhat obscure locations, 'almost as if to express embarassment about this formal adherence to the conventions of an international journal' (Clyne 1987: 229), whereas English authors place them at or near the beginning of their texts and are thus able, Clyne concludes, to make up for potential non-linearity.

Similar considerations apply to definitions. Clyne shows that English academics are more likely than their German colleagues to define technical terms, and also to place their definitions near the start of their texts. The perceived difference may, however, be due to different definitions of the term 'definition' itself, as Stolze/Deppert (1998) point out. In the humanities whole books may, after all, be devoted to defining complex terms such as 'translation equivalence'.

In view of our above discussion of composition instruction, it is hardly surprising to learn that texts by English-educated scholars show a greater percentage of topic sentences than those by German academics. Germans are far more likely to fall back on bridge sentences for paragraph linkage.

Finally, it is important to note that German-educated scholars tend to employ 'Germanic' discourse patterns when writing in English. In fact, these patterns become even more marked in their English texts, probably because much processing capacity is used up at the linguistic level in second language writing (Clyne 1987: 233).

A number of criticisms have been levelled at the above studies. The most general is that Clyne fails to reveal his corpus sources (cf. e.g. Sachtleber 1993: 65). Another is that Clyne's concepts of linearity and digressiveness, as well as his method of text analysis, are not defined in sufficient detail for them to be tested against other data than his own (cf. Hutz 1997: 67). Hutz (1997: 67) goes so far as maintaining that Clyne and Galtung sometimes succumb to the temptation of sweeping oversimplification ('populistische Pauschalisierungen'), but this is itself an exaggeration. It is in the nature of research to generalize across individual experiences, and this is exactly what Clyne does. While his findings may not apply to all German writers, they certainly point to common tendencies. Closely linked with Hutz's criticism are warnings that Anglo-American style may be held up as a norm to be emulated at any price, with the writing styles of other linguacultures appearing as deviations from this norm (see Pöckl (1995); see below). It is also claimed that this Anglo-American norm, as por- 
trayed in a substantial section of the composition literature, is based on an idealized notion of the English paragraph. As Kachru (1995: 181) points out,

most real texts, even within the American culture, exhibit variation from the idealized pattern(s). The repetitions of Arabic and the circularity of Indian writing occur in native English as well.

A number of German studies have gone some way towards sharpening the picture emerging from Clyne's studies. By focussing on text-type specific differences, they have managed to avoid the danger of oversimplification.

Oldenburg (1992) makes multivariate comparisons between conclusions and summaries found in English and German journal articles from various disciplines. His intralingual comparisons show that divergences between the English-language journals are more marked than those between the German-speaking journals. Interlingually, he finds that differences between summaries are least significant in the engineering sciences (e.g. Journal of Applied Mechanics vs. Forschung im Ingenieurwesen) and most significant in the language sciences (e.g. Language vs. Linguistische Berichte).

Trumpp (1996) compares English, French and German journal articles, reviews and abstracts in the field of sports science, producing highly intriguing findings: ${ }^{5}$

1. In journal articles there are significant differences between languages with respect to the use of topic and bridge sentences. Around 63 per cent of English paragraphs start with a topic sentence, whereas the figures for French and German are considerably lower, at 40 and 36 per cent respectively. Not so with reviews, where the topic sentence predominates in all three languages.

2. Metacommunicative statements are as common in reviews as in journal articles, whereas advance organizers occur with insignificant frequency in reviews - a clear, if predictable, contrast with journal articles. Advance organizers are found to be used with equal frequency in the languages under investigation, thus contradicting Clyne's finding that such elements are more commonly used in articles by native English writers.

3. Both in reviews and in journal articles, the genera verbi are used with differing frequencies in each of the languages examined. Agents are named significantly more frequently in French than in the two other languages. As it is generally agreed that the naming of agents is an important factor in fostering clarity of style (e.g. Williams 1990), this would seem to confirm the old adage 'ce qui n'est pas clair n'est pas français' (Rivarol). Contrariwise, the highest proportion of impersonal expressions (5.5 per cent) occurs in German writing.

4. While no one textual building block is peculiar to just one language, there is significant cross-cultural difference in the space given to each. Only 40 per cent of German journal articles contain a summary of findings, as against 65 per cent of English articles and 54 per cent of French articles. Contrastingly, 92 per cent of German articles contain an evaluation of the significance of the findings presented, while the figures for English (77 per cent) and French (79 per cent) are somewhat lower. It is also noteworthy that English reviewers, at 89 per cent, rate information on prospective readers as highly important, whereas French reviewers set greatest store by an account of the author's academic background. The greatest common denominator in German reviews appears to be information on price, at 75 per cent.

5. English and French reviewers are more reader-oriented. In their great majority, they consider it very important to provide information on the structure of the work under review. Only a third of German reviewers think it necessary to touch upon this point.

6. German reviewers, especially when writing reviews for academic colleagues, tend to take a more critical stance than their English and French counterparts. Editorial matters 
aside, English reviewers appear to be practical and constructive in their criticism, focussing, as they do, on suggestions for improvement. They also use considerably more hedges and considerably fewer parentheses than their Continental colleagues.

7. German reviewers tend to be more variable in their use of reporting verbs than their English and French colleagues, a result that contrasts significantly with findings on newspaper texts, where French can be shown to exhibit much greater variability.

Trumpp's study is methodologically sound, with very few misjudgements due to insufficient data. One error concerns the frequency of self-referencing. Finding no evidence of this practice in French reviews, she leaves the reader to conclude that it does not occur. However, a quick trawl through an academic corpus throws up a number of self-referenced passages starting with l'auteur de ces lignes or l'auteur de ce compterendu.

Hutz (1997) undertakes a micro- and macrostructural comparison of Germanand English-language articles in the field of social psychology. The picture emerging from his study is a complex one; texts are shown to be similar in some respects and to differ in others. For example, the macrostructure of German texts appears to be more variable than that of English texts. Hutz also claims that no definitive judgment can be made on the question of writer responsibility: while in the English corpus there is a higher frequency of metalanguage designed to make text structuring intelligible and to aid text comprehension, the German texts contain a larger number of markers of logical relationships (Hutz 1997: 173ff.; 240-241). In Hutz's view, this invalidates any claims to the effect that Anglo-American writers assume a higher degree of responsibility for their readers.

However, as is evident from his exemplificatory list (Hutz 1997: 175), Hutz gives almost exclusive consideration to lexicalized marker words such as thus, therefore, for example, ähnlich, allerdings. Although he briefly mentions Sinhaneti's (1982) structural classification of discourse devices, which includes some basic multi-word markers or 'lexical phrases', there is no indication that he attempted to compile anything like a representative inventory of these. When he says, for instance, that within the functional category 'exemplification' the marker for example accounts for 95 per cent of all occurrences in the Journal of Social Psychology (Hutz 1997: 181), it is immediately apparent that he disregards the huge number of multi-word markers (Siepmann 2001) belonging to this category. This is a serious oversight; it is perfectly possible to have a single-word lexicalized device in one language where the other language resorts to the use of a multi-word marker or to other lexical means. ${ }^{6}$ My suspicion is that Hutz's failure to take such correspondences into account may have seriously skewed his results on writer responsibility.

In a study of my own (Siepmann, forthcoming) I carried out frequency counts on parallel corpora of English, French and German multi-word exemplifiers such as to take an example or un exemple nous est fourni par + NP. The findings show that French exemplifiers occur with significantly higher frequency than English or German items. My study thus provides empirical support for the hitherto unfounded claim (cf. Vinay and Darbelnet 1958: 222) that, on average, French writers make more extensive use of connectors than their English or German counterparts.

At a broader level, however, it seems a moot point whether, as tacitly assumed by Hutz (1997), high frequency of logical markers can serve as a defining feature of writer responsibility in the first place. One counter-argument is the possibility of camouflag- 
ing incoherence or digression by means of logical markers (cf. Blumenthal 1997: 122-123). This usually happens when authors have not properly thought through their text and lack the will or time to revise it; it is fair to assume that such bad practice is particularly common in the German linguaculture, which favours reader responsibility rather than reader orientation. Blumenthal (1997: 122-123) provides the following example:

Staatliche Krisenbekämpfungspolitik: Vorerst schreckte die Staatsgewalt überall vor massiven Eingriffen in das Wirtschaftsgefüge und in das Kreditwesen zurück; sie übte eine Politik der Sparsamkeit im Bestreben, angesichts der sinkenden Steuereingänge den staatlichen Finanzhaushalt durch Senkung der Ausgaben im Gleichgewicht zu halten. Der Staat schränkte seine Bautätigkeit ein; er kürzte Gehälter und Sozialleistungen. Eine solche Politik verstärkte die deflatorische Entwicklung, aber Budgetdefizite und damit Verschuldung der öffentlichen Hand schienen die Gefahr einer neuen Inflation zu bergen. (from a history textbook cited in Blumenthal 1997)

Blumenthal comments that this use of aber presupposes an inference requiring a great deal of world knowledge. It is, as he puts it, a 'fig leaf concealing a slight thematic digression'. The sentences which would have to be interpolated to make the inference fully explicit are as follows:

Eine alternative Wirtschaftspolitik hätte darin bestehen können, die Deflation durch deficit spending zu bekämpfen; entsprechende Vorschläge fanden keinen Anklang, denn... (Blumenthal 1997: 122-123)

Secondly, there is the fact that some accomplished British and American writers, such as John D. Gallagher, make liberal use of logical and other markers, whereas others, such as Walter Nash, eschew metadiscursive words and phrases altogether. By the same token, English-language style guides differ considerably with regard to the stance taken on metatext (cf. Mauranen 1993: 168). Even though only psycholinguistic research could provide a definitive answer as to who is right in this debate, such facts encourage the assumption that both types of writing can have clarity and grace as long as certain other conditions obtain. ${ }^{7}$ For an impressionistic answer, compare the following texts:

FIGURE 1

A comparison of two paragraphs (Nash 1980: 12-13)

\begin{tabular}{|l|l|}
\hline (1) Paragraph without Metadiscourse & (2) Paragraph with Metadiscourse \\
\hline $\begin{array}{l}\text { There is something wrong with the morality } \\
\text { of a saying like 'Honesty is the best policy'. }\end{array}$ & $\begin{array}{l}\text { There is something wrong about the morality of } \\
\text { a saying like 'Honesty is the best policy'. For one } \\
\text { thing, the readiness to weigh virtue in the scale } \\
\text { profit. Any tolerably observant person must } \\
\text { of calculable profit is in itself deplorable. For } \\
\text { another, there are clearly a great many occasions } \\
\text { countless occurrences in life when doing } \\
\text { what we believe to be right does not bring } \\
\text { us material rewards. Indeed we may } \\
\text { sometimes suffer for it. To offer sound } \\
\text { policy as an excitement to good morals is } \\
\text { therefore in itself dishonest. Honesty, if it } \\
\text { requires a motive, must be valued for } \\
\text { reasons other than politic. (Nash 1980: 12) }\end{array}$ \\
$\begin{array}{l}\text { Furthermore, if we encourage young people to } \\
\text { believe that they will always be materially or } \\
\text { socially better off for being honest, they will } \\
\text { discover by experience the falsity of this claim } \\
\text { and will be inclined to regard us as fools or } \\
\text { hypocrites. All in all, it seems clear that honesty, } \\
\text { if it requires a motive, must be valued for } \\
\text { reasons other than politic. (Nash 1980: 13) }\end{array}$ \\
\hline
\end{tabular}


In the first paragraph, Nash achieves coherence simply by making every sentence depend on the topic sentence and weaving through the piece sets of conceptually related words (e.g. wrong, wrongness, false; equation-equation; policy-politic; incitement-motive; good morals-honesty). In fact, each sentence develops directly from the topic sentence and the whole is rounded off by a concluding sentence which drives home the main point. The second version follows an - arguably - cruder procedure in that it makes enumerative markers do the job of tying the text together. On the whole, it seems fair to say that both versions manage the flow of information with the same clarity of style, though the first has the additional merit of a certain quiet elegance. This goes some way towards demonstrating that the absence of logical markers need not necessarily create difficulties for the reader.

Sachtleber's (1993) analysis of German and French proceedings of linguistics conferences brings into focus new aspects of such concepts as 'clarity' and 'linearity'- even though the study is written in a somewhat turgid style and fails to distinguish between the effects of language structure on the one hand and culture on the other. Applying Searle's concept of speech act to larger units, Sachtleber posits the existence of 'text acts', of which she numbers four in the study in question (68-69): thematising, commenting, referring and organising. Her basic hypothesis is that the occurrence of certain text acts is constitutive of a specified text type, no matter which language that text type occurs in; at the same time, however, the frequency with which text acts occur in a specified text type will differ from one language to another, with the result that text acts have an immediate bearing on the language-particular realization of each text type. Testing this hypothesis on her corpus, Sachtleber finds that French articles have a higher proportion of thematising text acts ( 82 per cent) than German articles (65 per cent), with the obvious consequence that the German conference proceedings show a greater variety of different text acts. With regard to textual macrostructure, Sachtleber's findings show that half the French authors write at only one thematic level; that is, they link adjacent parts of a descriptive discourse mainly by means of causal or pars pro toto relations operating at the same hierarchical level. The great majority of German authors, on the other hand, are found to prefer specification, meaning the frequent switching from one hierarchical level to the next higher or lower level. Furthermore, German authors are found to be less apt than their French counterparts to introduce metalanguage when making a transition from one subject to another. Sachtleber concludes:

These results show that there is no point in describing the style of a text type as 'linear' and 'disciplined', or as 'muddled' and 'digressive', as the case may be, without making further distinctions. Rather, one should try to pinpoint the structural level at which differences exist. Does 'digressiveness' mean that the writer integrates too many comment sections into his account or does it mean that specification is taking place at more than three hierarchical levels, thus hindering readers from following the thread of the argument? Does 'linearity' or 'clarity' refer to an explanatory account whose logicosemantic relations are marked at the text surface, i.e. whose organisation is functional, or do these terms refer to a text in which one text act predominates and in which the writer thus limits himself to using only a minimum of other text acts? ${ }^{8}$

The answer to those rhetorical questions is, of course, 'one or the other, or a mixture of the two'. The terms 'clarity' and 'linearity' can refer to phenomena at any level of text organisation, from the compound noun phrase to the entire text. Just as the use 
of agents in subject position helps achieve clarity at sentence level, so it is for the use of thematic strings at paragraph level. At the next higher level, Sachtleber's text acts play an important role, determining, as they do, the content and structure of one or more paragraphs. The ways in which a writer handles such determinants of text organisation help to promote or undermine, as the case may be, the coherence of a text.

Generally speaking, coherence depends on linguistic devices such as substitution as well as on extralinguistic givens such as shared knowledge. In his study of the micro- and macrostructure of French and German history textbooks, Blumenthal (1997: 112-128) demonstrates that the two genres differ with regard to the role played by linguistic and extralinguistic phenomena in creating coherence. German texts of this kind make higher demands on the reader's world knowledge and ability to bridge logical gaps; specifically, they foreground linear temporal structuring, part-whole relationships and contiguity. Compare this with the French texts discussed by Blumenthal, in which relations of identity, opposition and specification/inclusion carry a special prominence. At the highest level of generalization, we might say that French texts engender a more conscious channeling of the reader's perception and understanding than German texts, which tend to be more indeterminate. Thus, on a scale of ascending determinacy, German would be placed lower than English, and English lower than French.

If the foregoing analysis of coherence was along the right lines, we might expect power structures to be reflected differently in English, French and German text. The assumption might be that the indeterminacy of German texts would offer the greatest potential for concealing weaknesses in the writer's line of argument, while the highly explicit coherence patterns of French texts would make this difficult. And such is indeed the case, as a strand of research shows which is concerned with the negotiation of interpersonal meaning in academic discourse, notably through such devices as hedging.

In this area much more attention has been given to academic English than to any other language, with monolingual studies on abstracts (Rounds 1982), science digests (Fahnestock 1986) and medical discourse (Salager-Meyer 1994, Myers 1989). Of particular interest to the languages here investigated is Kreutz's and Harres's ongoing study of the distribution and function of hedging in German and English academic writing (Kreutz and Harres 1997). This study suggests that particles may serve different purposes across languages: whereas the primary function of German particles appears to be that of asserting the writer's authority, English particles serve mainly to 'downtone and mitigate arguments and assertions' (Kreutz and Harres 1997: 181). This assertion finds support in Tim John's suggestions on how best to convey an attitude of academic modesty in English scholarly prose, where it is not very common to describe one's own work as useful or interesting; rather, the writer is expected to use a downtoner such as 'I hope' or 'it is hoped that' (Johns 1998). Other parallels may be seen in House's finding that Germans are perceived to be more direct and explicit than the British in their oral interactions as well as in Blumenthal's aforementioned observation (1998: 123) that some German connectors may serve to camouflage a lack of cohesion.

To avoid drowning the reader in a multitude of detail, it is time now to briefly summarize our findings on academic thinking and writing styles in the three languages 
under investigation. The following table lists criterial features central to a discussion of stylistic difference between languages in academic, popular-scientific and journalistic writing.

FIGURE 2

A summary of stylistic differences

\begin{tabular}{|c|c|c|c|}
\hline & English & French & German \\
\hline $\begin{array}{l}\text { Relationship between } \\
\text { Writer and Reader } \\
\text { (Mauranen 1993, } \\
\text { Schröder 1988) }\end{array}$ & $\begin{array}{l}\text { writer responsibility: } \\
\text { the reader is assumed } \\
\text { to have less subject } \\
\text { knowledge than the } \\
\text { writer; he needs to be } \\
\text { told why the text is } \\
\text { worth reading and } \\
\text { what is important }\end{array}$ & $\begin{array}{l}\text { writer responsibility: } \\
\text { the reader is assumed } \\
\text { to have less subject } \\
\text { knowledge; the } \\
\text { author takes him } \\
\text { through the text, } \\
\text { adjacent parts of } \\
\text { which are clearly } \\
\text { linked by (e.g.) causal } \\
\text { or pars pro toto } \\
\text { relations operating at } \\
\text { the same hierarchical } \\
\text { level }\end{array}$ & $\begin{array}{l}\text { reader responsibility: } \\
\text { the reader is assumed } \\
\text { to share the writer's } \\
\text { subject knowledge; } \\
\text { frequent switching of } \\
\text { hierarchical levels }\end{array}$ \\
\hline $\begin{array}{l}\text { Overall coherence } \\
\text { (Blumenthal 1998) }\end{array}$ & $\begin{array}{l}\text { explicit coherence } \\
\text { through fairly } \\
\text { consistent topic and } \\
\text { thematic strings }\end{array}$ & $\begin{array}{l}\text { explicit coherence } \\
\text { through fully } \\
\text { consistent topic and } \\
\text { thematic strings: } \\
\text { author pre-deter- } \\
\text { mines principle of } \\
\text { knowledge organisa- } \\
\text { tion (e.g. through } \\
\text { binary oppositions) }\end{array}$ & $\begin{array}{l}\text { implicit coherence: } \\
\text { author relies heavily } \\
\text { on reader's world } \\
\text { knowledge and } \\
\text { inferences; risks } \\
\text { obscuring the } \\
\text { message, but leaves } \\
\text { interpretation open }\end{array}$ \\
\hline $\begin{array}{l}\text { Text structures } \\
\text { (Schröder 1988) }\end{array}$ & $\begin{array}{l}\text { 'point-early', linear } \\
\text { structure: the main } \\
\text { point is usually made } \\
\text { at the outset of the } \\
\text { argument }\end{array}$ & $\begin{array}{l}\text { 'point-early' or 'point- } \\
\text { late' (the latter mainly } \\
\text { in classical disserta- } \\
\text { tions, newspaper } \\
\text { comments, essays) }\end{array}$ & $\begin{array}{l}\text { 'point-late', spiral-like } \\
\text { structure: theoretical } \\
\text { exposition prepares } \\
\text { for the main point to } \\
\text { be made at the end of } \\
\text { the argument }\end{array}$ \\
\hline $\begin{array}{l}\text { Text acts (Sachtleber } \\
\text { 1993) }\end{array}$ & $\begin{array}{l}\text { preference for one } \\
\text { continuous text act }\end{array}$ & $\begin{array}{l}\text { Preference for one } \\
\text { continuous text act; } \\
\text { 'erklärend-darstel- } \\
\text { lende Deskription' }\end{array}$ & $\begin{array}{l}\text { Preference for a } \\
\text { variety of text acts; } \\
\text { 'spezifizierende } \\
\text { Deskription' }\end{array}$ \\
\hline $\begin{array}{l}\text { Metalanguage (Hutz } \\
\text { 1997, Mauranen 1993, } \\
\text { Siepmann, forthcom- } \\
\text { ing) }\end{array}$ & $\begin{array}{l}\text { high proportion in } \\
\text { some major text } \\
\text { segments } \\
\text { (Introduction, } \\
\text { Method, Discussion); } \\
\text { high proportion of } \\
\text { markers intended to } \\
\text { structure text and to } \\
\text { secure understanding }\end{array}$ & $\begin{array}{l}\text { high proportion } \\
\text { throughout }\end{array}$ & $\begin{array}{l}\text { generally lower } \\
\text { proportion than in } \\
\text { English and French }\end{array}$ \\
\hline $\begin{array}{l}\text { Paragraph Structure } \\
\text { (e.g. Trumpp 1998) }\end{array}$ & $\begin{array}{l}\text { topic sentence tends to } \\
\text { control paragraph } \\
\text { structure }\end{array}$ & $\begin{array}{l}\text { bridge sentence } \\
\text { identifies position in } \\
\text { line of argument; } \\
\text { topic sentences only } \\
\text { moderately common }\end{array}$ & $\begin{array}{l}\text { no unified model of } \\
\text { paragraph structure; } \\
\text { topic sentences } \\
\text { comparatively rare }\end{array}$ \\
\hline
\end{tabular}




\begin{tabular}{|l|l|l|l|}
\hline $\begin{array}{l}\text { Logico-semantic } \\
\text { relations and marker } \\
\text { use (e.g. Vinay/ }\end{array}$ & $\begin{array}{l}\text { fairly small choice of } \\
\text { one-word discourse } \\
\text { markers } \\
\text { Quillard/Akhras 1996, } \\
\text { Blumenthal 1998, } \\
\begin{array}{l}\text { Siepmann, forthcom- } \\
\text { ing) }\end{array}\end{array}$ & $\begin{array}{l}\text { rich and varied choice } \\
\text { of markers; high } \\
\text { degree of correspon- } \\
\text { dence between } \\
\text { marker use and text } \\
\text { structure; preference } \\
\text { for subordination }\end{array}$ & $\begin{array}{l}\text { wide choice of } \\
\text { markers; these are } \\
\text { clearly marked at the } \\
\text { text surface, but may } \\
\text { sometimes mask a } \\
\text { lack of coherence; } \\
\text { preference for } \\
\text { coordination }\end{array}$ \\
\hline $\begin{array}{l}\text { Textual modality and } \\
\text { hedging (Kreutz \& } \\
\text { Harres 1997) }\end{array}$ & $\begin{array}{l}\text { hedges as downtoners } \\
\text { and mitigators }\end{array}$ & (no studies available) & $\begin{array}{l}\text { hedges serve to assert } \\
\text { authority }\end{array}$ \\
\hline $\begin{array}{l}\text { Authorial self- } \\
\text { reference } \\
\text { (Hutz 1997, Trumpp } \\
\text { 1998) }\end{array}$ & $\begin{array}{l}\text { more authorial } \\
\text { statements (I/we) }<-> \\
\text { cooperative writing } \\
\text { style }\end{array}$ & $\begin{array}{l}\text { frequent use of the } \\
\text { majestic plural }\end{array}$ & $\begin{array}{l}\text { fewer 'personal' } \\
\text { statements; more } \\
\text { impersonal construc- } \\
\text { tions (e.g. man); } \\
\text { higher use of } \\
\text { inclusive we (here we } \\
\text { have a ...) }<-> \\
\text { author-centred } \\
\text { writing style }\end{array}$ \\
\hline Naming of agents & $\begin{array}{l}\text { preference for } \\
\text { nominalized agents in } \\
\text { subject position }\end{array}$ & $\begin{array}{l}\text { preference for } \\
\text { nominalized agents in } \\
\text { subject position }\end{array}$ & $\begin{array}{l}\text { avoidance of nomi- } \\
\text { nalized agents in } \\
\text { subject position }\end{array}$ \\
\hline
\end{tabular}

\section{Plurality of Styles vs. Monoculture}

It remains for us to consider the implications of stylistic difference for each of the linguacultures concerned: should Anglo-Saxon style provide the role model for composition in other languages, or is there a case for preserving the present plurality of styles?

It has been claimed that British and American contrastive rhetorics is guilty of 'naive Anglo-American ethno- or glottocentrism' (e.g. Pöckl 1995). Pöckl correctly points out that almost all British and American authors tend to use positive terms ('linear', 'symmetrical') for Anglo-Saxon style, whereas their descriptions of foreign discursive conventions appear to be loaded with negative implications ('non-linear', 'asymmetrical', 'incoherent'). That such a view is partial should be obvious; inverting the black-and-white dichotomy, we might state with equal plausibility that German texts, by virtue of their digressiveness, are versatile and multi-faceted, whereas AngloSaxon writing is repetitive and colourless. Equally, German text structure might be likened metaphorically to that of a 'staircase' or 'spiral' (Pöckl 1995: 103) leading the writer through ever more complex stages of reasoning to the conclusion. Viewed from this perspective, English academic style will appear like a walk over perfectly flat country with no attempt to venture into mountainous territory.

While the infelicitous use of terminology in Anglo-American contrastive rhetorics cannot be denied and should be remedied, European critics like Pöckl seem to forget that Clyne, for example, does not see German 'Exkurse' in wholly negative terms. For him they have a discernible and useful function - that of familiarizing the reader with a theory, of introducing new perspectives or of providing historical background. A consensus model that sets a positive example in using neutral terminology is House's 1997 (84ff.) summary of cross-cultural difference. 
Where Pöckl (1995) clearly goes astray is in his charge that native English writers and readers are ethnocentric because they are loath to inch their way through research articles that violate Anglo-Saxon norms. Just as foreign-language conversation classes aim to 'produce' a learner who can function adequately in the target community through adherence to both social and linguistic conventions, in the same manner it seems only natural to expect non-native writers to make the effort to meet targetlanguage readers' expectations: when in Rome, do as the Romans do. Needless to say, this line of reasoning applies equally to any language, not just to English. Plainly, Pöckl (1995: 104-105) overstates his case by raising fears about the loss of non-Anglophone identities, while at the same time disregarding the fact that non-native researchers' failure, or reluctance, to acquire a genuinely English writing style would only strengthen the predominance of Anglo-American scientists (for the simple reason that the former would no longer be read by the latter).

On the other hand, every effort should be made to preserve the present plurality of linguacultures through adequate writing instruction in each language (cf. Pöckl 1995: 105, Hoberg 1987). Without such efforts there is a real danger that uniformity and monoculture will be the order of the day, seriously constraining the linguistic, conceptual and methodological richness afforded by the current diversity of linguacultures and world-views (Hoberg 1987). We may make an analogy with the natural world, where many animal and plant species have been driven to extinction. In a parallel fashion, Bossong (1992: 108) argues, Arab and Chinese traditions of scientific investigation run the risk of being irreversibly supplanted by Western approaches.

The whole question of writing styles also brings aesthetic concerns to the fore, concerns which have for a long time suffered benign neglect in the literature. Under the twin pressures of teamwork and time constraints, many academics omit to revise their papers structurally (Pöckl 1995: 105), let alone respond to the exigencies of literary style (Chargaff 1986: 108). If we accept that different writing styles should be preserved and taught, then it would be only logical to collate the writings of some of the most renowned stylists in each linguaculture with a view to ferreting out their essential skills. It is to be hoped that such renewed debate about, and instruction in, culture-specific writing styles will lead to an increase in the demand for texts of high stylistic quality (cf. also Pöckl 1995: 105). The above portrayal of the French system suggests that the stylistic quality of a linguaculture's textual output hinges on the quality of writing instruction and the severity of examinations.

This, of course, is not to deny that there has recently been a growing internationalisation of text-type norms operating at the macro-level of paragraphs or sections. For example, many German and French journals now accept publications in English and have adopted Anglo-Saxon norms for the structure and presentation of articles.

\section{Implications for Translation}

A related issue concerns the ways in which translators are to cope with cross-cultural difference in linguistic micro- and macrostructures. Following my above line of reasoning, I would reject the compromise between preservation and adaptation suggested by Stolze/Deppert (1998: 127):

This does not mean that all texts have to be recast completely when being transferred to another culture; an author's mentality is part of the meaning of his or her text and 
should not be eliminated. However, rewriting is not generally out of place. It is especially useful with regard to syntax and the arrangement of particular ideas [...] It is also useful where language-particular syntax, metalanguage, text type norms and logical defects impair text comprehension. ${ }^{9}$

On closer inspection, this argumentation proves to be a contradiction in terms, for almost any academic text will show language-specific syntax and text-type norms, with the result that it will have to undergo syntactic and text-structural changes in translation. My plea, then, would be for optimum adherence to the stylistic norms of the target language.

The restricted space here available precludes my considering the impact of stylistic difference on a full-length academic translation. I have therefore singled out three examples which demonstrate 'stylistically faithful' translation at various levels of complexity: inter-sentence and interparagraph linkage based on multi-word restrictors, use of stylistic devices and text organization across languages. The default assumption here is functionally constant translation for an academic audience.

The first example concerns a translation error occurring in the German translation of Capra's well-known popular science book The Tao of Physics. This error will serve to illustrate that syntactic and text-structural shifts may be necessary even in cases where text comprehension is not impaired:

Hier sollte vielleicht ein Wort der Vorsicht eingefügt werden. Die Betonung des Sehens (Schauens) in den mystischen Traditionen ist nicht allzu wörtlich, sondern in einem metaphorischen Sinne zu verstehen ... (Capra 1983: 33; my emphasis)

In the present case the German translators have opted for a clumsily literal translation of an English multi-word restrictor (cf. Siepmann 2001, forthcoming) based around the collocation word of caution. In idiomatic German collocations with Wort can be classified into two main groups, viz. a) Wort + source of the word(s) in consideration: Wort des Herrn, Wort des Bundeskanzlers, Wort des Dichters), b) Wort + content of the word(s) in consideration: Wort des Abschieds, Wort des Dankes, Wort der Erklärung, Wort der Entschuldigung). It might be argued that Wort der Vorsicht is a neologism based on group b); however, the noun phrases in group b) usually perform a summative function and have text-external reference to a speech act which occurred before the moment of speaking or writing. The opposite is true of word of caution which cataphorically announces the passage it refers to (a word of caution is in order: ...). In German the same cataphoric function is served by verb-based multi-word restrictors introducing a matrix clause, so that a translation which conforms to targetlanguage norms would read as follows:

Hier ist allerdings zu beachten, dass / hier möchte ich zu bedenken geben, dass / hier wäre allerdings zu bedenken / bei alldem ist zu bedenken, dass die Betonung des Sehens (Schauens) in den mystischen Traditionen nicht allzu wörtlich, sondern in einem metaphorischen Sinne zu verstehen ist ...

My second example concerns the use of stylistic devices in academic writing. Both Colson (1993) and Trumpp (1997: 211) note that, when translating French scholarly prose into other languages, it may be necessary to pare down the number of stylistically elaborate wordings by replacing them with neutral formulations. Conversely, translators working into French may have to phrase their target texts more elegantly than the original. Colson (1993) gives the following example: 
146 MetA, LI, 1, 2006

FIGURE 3

An English philosophical text and its French translation

\begin{tabular}{|c|c|}
\hline English original & French translation \\
\hline $\begin{array}{l}\text { Two hundred years ago, in 1784, Kant } \\
\text { responded to the question posed by a Berlin } \\
\text { newspaper: 'What is enlightenment?' by } \\
\text { equating enlightenment with the attainment } \\
\text { of maturity through the use of reason. Since } \\
\text { then the meaning of this claim has been } \\
\text { debated periodically. Today the question has } \\
\text { again been raised in the public arena by the } \\
\text { two thinkers who could legitimately be called } \\
\text { the heirs to this debate because they embody } \\
\text { two opposed but equally serious and persua- } \\
\text { sive ways of reinterpreting the philosophic life } \\
\text { through understanding the relationship } \\
\text { between reason and the historical moment. } \\
\text { The question also lies behind the writing of } \\
\text { those anti-thinkers who, in the name of post- } \\
\text { enlightenment and post-modern discourse, } \\
\text { question seriousness in general. }\end{array}$ & $\begin{array}{l}\text { C'est il y a deux siècles, en 1784, que Kant, } \\
\text { répondant à la question que posait une revue } \\
\text { berlinoise: Qu'est-ce que les lumières? identifia } \\
\text { le progrès des lumières à l'accession à l'âge } \\
\text { d'homme, par l'usage de la raison. Depuis lors, } \\
\text { on n'a pas manqué de disputer du sens auquel } \\
\text { cette thèse devait être entendue, et d'en } \\
\text { reprendre régulièrement l'instruction. A } \\
\text { l'heure actuelle, la question revient en délibéré } \\
\text { auprès du public, à l'instance des deux penseurs } \\
\text { pouvant prétendre, à bon droit, au titre d'héri- } \\
\text { tiers de ce débat, en ce qu'ils incarnent deux } \\
\text { modes opposés, mais également garants de } \\
\text { sérieux, et emportant une égale conviction, de } \\
\text { se pourvoir en réinterprétation de ce qu'est la } \\
\text { vie philosophique, motivés par l'appréhension } \\
\text { de la relation intervenant entre raison et } \\
\text { moment historique. Et c'est d'ailleurs cette } \\
\text { même question qui sous-tend les écrits de ces } \\
\text { anti-penseurs qui, arguant du discours de la } \\
\text { postmodernité et de la post-Aufklärung, } \\
\text { remettent en cause l'esprit de sérieux en son } \\
\text { principe général. }\end{array}$ \\
\hline
\end{tabular}

It is evident that the translation is couched in a considerably more ornate style than the original. The translator has substituted a finely crafted legal metaphor (cf. reprendre l'instruction, revient en délibéré, se pourvoir en réinterprétation, arguant $d u$ discours) for the blunt professional-functional prose of the original (claim, debate, raise a question, reinterpreting, understanding), thus producing a target text which conforms to the norms of French philosophical writing (cf. Colson 1993: 436).

Lastly, let us consider the question of text organization, using biographical recounts as an example. The following texts provide typical examples:

FIGURE 4

\section{A comparison of biographical recounts in German and English}

\begin{tabular}{|c|c|}
\hline German original & English translation \\
\hline $\begin{array}{l}\text { Lion Feuchtwanger wurde } 1884 \text { in München } \\
\text { geboren. Nach vielseitigen Studien gab er die } \\
\text { Kulturzeitschrift Der Spiegel heraus, schrieb } \\
\text { Theaterkritiken und arbeitete an der } \\
\text { Schaubühne mit. Bei Ausbruch des Ersten } \\
\text { Weltkrieges wurde Feuchtwanger in Tunis } \\
\text { interniert, konnte jedoch fliehen. In München } \\
\text { vom Wehrdienst suspendiert, nahm er die } \\
\text { Übersetzung und Bearbeitung indischer, } \\
\text { griechischer und spanischer Dramen wieder } \\
\text { auf, zudem entstanden eigene Stücke und } \\
\text { Antikriegsdichtung. 1918/19 begann die }\end{array}$ & $\begin{array}{l}\text { Lion Feuchtwanger was born in } 1884 \text { in } \\
\text { Munich, Germany. After studying a wide range } \\
\text { of subjects at Berlin and Munich he founded a } \\
\text { literary magazine, Der Spiegel, wrote theatrical } \\
\text { reviews and worked at the Schaubühne. At the } \\
\text { beginning of World War I Feuchtwanger was } \\
\text { interned in Tunis, but managed to escape. } \\
\text { Suspended from military service in Munich, } \\
\text { he resumed the translation and adaptation of } \\
\text { Indian, Greek and Spanish dramas; at the } \\
\text { same time he wrote plays of his own as well as } \\
\text { anti-war poetry. In 1918/19 he began to }\end{array}$ \\
\hline
\end{tabular}


freundschaftliche Zusammenarbeit mit Brecht. Die bayrische Räterepublik erlebte er "in großer Nähe führender Männer”. Die historischen Romane Die häßliche Herzogin Margarete Maultausch und Jud Süß brachten Feuchtwanger Weltruhm. 1925 siedelte er nach Berlin über. Als die Nazis die Macht übernahmen, war er auf Vortragsreise in den USA. Seine Bücher wurden verboten, Haus und Vermögen konfisziert. Sanary-sur-Mer, Feuchtwangers neuer Lebensort, war zeitweilig ein Zentrum deutscher Emigranten. Hier vollendete er u.a. die Wartesaal- und die Josephus-Trilogie. Ende 1936 fuhr er in die UdSSR (Moskau 1917, Ein Reisebericht für meine Freunde). 1940 internierten ihn die Franzosen. Ab 1941 lebte er in Kalifornien, wo große historische Romane, Erzählungen, Stücke und Essays entstanden. Feuchtwanger starb 1958 in Pacific Palisades. (Lion Feuchtwanger, Die Brüder Lautersack, Berlin, 1977) collaborate with his friend Berthold Brecht. In the Bavarian socialist republic (Räterepublik) he maintained close contacts with a number of prominent men. His historical novels The Ugly Duchess and Jew Süss earned him world fame. In 1925 Feuchtwanger moved to Berlin. He was on a lecture tour in the United States when the Nazis assumed power in 1933; his books were banned, his house and property confiscated. Feuchtwanger fled to Sanary-surMer, which at that time was a temporary centre of German emigration. There he completed the Wartesaal and Josephus-Trilogie. Late in 1936 he went to the USSR; in 1940 he was interned by the French. From 1941 onwards he lived in California, where he wrote great historical novels, short stories, plays and essays. Feuchtwanger died in Pacific Palisades in 1958. (translated by Dirk Siepmann and John D. Gallagher)

Purser and Paul (1999) have demonstrated that English and German biographical recounts differ significantly in terms of their thematic organisation. English recounts consistently thematize the person and his or her work (Feuchtwanger $->$ he -> Feuchtwanger -> he, etc.); in Daneš' (1974) terminology they use 'constant theme'. In contrast, German writers vary themes to a greater extent, picking up the rheme of the preceding clause as theme ('thematic progress'), selecting circumstances as theme ('hypertheme': 1925 -> als die Nazis die Macht übernahmen) or placing rhemes in subject position (die freundliche Zusammenarbeit mit Brecht, die historischen Romane ..., Sanary-sur-Mer, große historische Romane, Erzählungen, Stücke und Essays).

\section{NOTES}

1. 'Among southern peoples language is an ingredient of life's joys which is held in much livelier social esteem than in the north. The honours paid by these nations to that national binder, the mother tongue, are exemplary, and there is something joyfully exemplary about the appreciation and awe with which they treat its forms and sounds. One speaks with pleasure, one listens with pleasure - and one listens with discernment.' (my translation)

2. Baccalaureate candidates are now given a choice between different types of writing tasks, with the result that the 'dissertation' type of essay tends to disappear at this level: 'les élèves pouvant choisir entre trois types de sujets: résumé et réécriture, argumentation et enfin dissertation, cette dernière a tendance à disparaître, comme naturellement, dans les choix des candidats. On peut prévoir que, à une date proche, la dissertation et l'explication de textes n'existeront plus que dans les concours de recrutement.' (Rousseau and Demarty-Warzée 2000)

3. The original reads: 'Ionesco écrit dans Notes et Contre-notes: "Le comique n'est comique que s'il est un peu effrayant." En vous appuyant sur votre expérience théatrâle et cinématographique, mais aussi sur les comiques dont vous connaissez les sketches, vous direz si cette affirmation correspond à l'idée que vous vous faites du comique.' (Amancy/Ventura 1992: 77)

4. To give a concrete example of what this means: In a series of televised translation courses (Boulton et al. 1997/1998), one of the lecturers warned students to beware of using the noun opportunité in the sense of English opportunity in their translations. The reason advanced for this warning was that the Académie française has not yet accepted this usage, which has been around for at least thirty years! 
5. Although one wonders about the significance of some results, such as the fact that 59 per cent of the English reviews examined contain information on pricing, as against 85 per cent of German reviews.

6. Hutz is not totally unaware of this: 'Durch andere Kohäsionsverfahren wie beispielsweise lexikalische Rekurrenz, Pro-Formen oder andere Verfahren der lexikalischen Kohäsion kann der geringe Einsatz von Textkonnektoren durchaus kompensiert werden' (Hutz 1997: 177), but does not follow this argument through to its logical conclusion.

7. Note also that writing which uses metadiscourse may be easier to produce because it contains more routine elements. The novice writer, especially the non-native, may therefore be well advised to use metadiscourse liberally in order to lighten his learning burden.

8. The original reads: 'Diese Ergebnisse machen deutlich, dass es nicht sinnvoll ist, undifferenziert von einem stringenten bzw. linearen oder konfusen bzw. digressiven Stil innerhalb einer Textsorte zu sprechen. Es ist dagegen wichtig zu beschreiben, innerhalb welcher Struktur Unterschiede bestehen. Ist mit dem Urteil "digressiv" gemeint, dass ein Autor zu viele kommentierende Textteile in seine Darstellung integriert, oder ist damit gemeint, dass die Spezifizierung sich auf mehr als drei Hierarchiestufen vollzieht und von den LeserInnen nicht mehr nachvollzogen werden kann? Ist mit "Linearität" oder "Klarheit" eine erklärende Darstellung gemeint, deren logisch-semantische Relationen an der Sprachoberfläche durch Gliederungssignale markiert sind, deren Textorganisation also funktional ist, oder ein Text, in dem vor allem ein Texthandlungstyp vorherrscht und sich der Autor bei der Verwendung anderer Texthandlungstypen auf das textsortenbedingte Minimum beschränkt?' (Sachtleber 1993: 77)

9. The original reads: 'Das heißt also nicht, dass alle Texte [all academic texts, D.S.] im interkulturellen Transfer völlig umgeschrieben werden müßten. Die "Mentalität" eines Autors ist vielmehr Teil des Textsinns und sollte nicht ausgemerzt werden. Das heißt aber nicht, dass Textbearbeitungen generell nicht sinnvoll sind: sie sind vor allem dort angebracht, wo es um den Satzbau geht und um die Anordnung vorhandener Inhalte [...] Außerdem sind sie da sinnvoll, wo einzelsprachspezifische Syntax, metasprachliche Formulierungen, Textsortennormen und logische Defekte die Textrezeption beeinflussen.

\section{REFERENCES}

Amancy, N. and T. Ventura (1992): 50 modèles de dissertation, Alleur, Marabout.

Blumenthal, P. (1997): Sprachvergleich Deutsch - Französisch (2nd ed.), Tübingen, Niemeyer.

Bossong, G. (1992): "Form und Inhalt in der Europäisierung nicht-europäischer Kultursprachen,"

Baum, R. and J. Albrecht (eds.), Fachsprache und Terminologie in Geschichte und Gegenwart, Tübingen, Narr, p. 79-114.

Boulton, A. et al. (1997/1998): Vidéocours. Anglais: Cours de traduction, Nancy, Université de Nancy 2.

Capra, F. (1983): Das Tao der Physik. Die Konvergenz von westlicher Wissenschaft und östlicher Philosophie, München, Knaur.

Chargaff, E. (1986): “How Scientific Papers are Written,” Fachsprache 8, p. 106-110.

Chirac, J. (1975): «La France devant les questions linguistiques», Discours prononcé par M. Jacques Chirac, Premier Ministre, le 7 fév. 1975, à l'invitation de l'Union Internationale des journalistes et de la presse de la langue française, Paris, Haut Comité de la langue française.

Clyne, M. (1981): “Culture and Discourse Structure," Journal of Pragmatics 5, p. 61-66.

Clyne, M. (1987): "Cultural Differences in the Organization of Academic Texts. English and German," Journal of Pragmatics 11, p. 211-247.

Clyne, M. (1991): "The Sociocultural Dimension: The Dilemma of the German-speaking Scholar," Schröder, H. (ed.) (1991) Subject-oriented Texts. Languages for Special Purposes and Text Theory, Berlin/New York, de Gruyter, p. 49-67.

Colson, J. (1993): “The Exquisite Sophistication of French Scholarly Writing: French Spirit or French Letter?," Meta 38-3, p. 426-439.

Dournon, F. (1994): Dictionnaire des mots et formules célèbres, Paris, Le Robert.

Fannestock, J. (1986): “Accommodating Science: The Rhetorical Life of Scientific Facts," Written Communication 3-3, p. 275-296. 
Galtung, J. (1981): “Structure, Culture and Intellectual Style." Social Science Formation 20, p. 817856.

GöTzE, K. H. (1993): Französische Affären. Ansichten von Frankreich, Frankfurt am Main, Fischer.

Hermanns, F. (1985): "Schreiben im Vergleich Wierlacher," Alois (ed.) (1985) Das Fremde und das Eigene: Prolegomena zu einer interkulturellen Germanistik, München, Iudicium, p. 123-139.

Hoberg, R. (1987): Sprache und Bildung: Beiträge zum 150. Todestag Wilhelm von Humboldts (THD-Schriftenreihe Wissenschaft und Technik 35), Darmstadt, THD.

House, J. (1979): "Interaktionsnormen in deutschen und englischen Alltagsdialogen," Linguistische Berichte 59, p. 76-90.

House, J. (1982a): “Opening and Closing Phases in English and German Dialogues," Grazer Linguistische Studien 16, p. 52-83.

House, J. (1982b): "Conversational Strategies in German and English Dialogues," N. Gerhard and D. Nehls (eds.) (1982) Error Analysis, Contrastive Linguistics and Second Language Learning, Heidelberg, Groos, p. 131-146.

House, J. (1982c): “Gambits in deutschen und englischen Alltagsdialogen," Grazer Linguistische Studien 17/18, p. 110-132.

House, J. (1989a): "Politeness in English and German," Blum-KulKa, S. et al. (eds.) (1989) CrossCultural Pragmatics: Requests and Apologies, Norwood, N.J., Ablex, p. 96-122.

House, J. (1989b): "Excuse me please: Apologizing in a Foreign Language," Kettemann, B. et al. (1989) (eds.) Englisch als Zweitsprache, Tübingen, Narr, p. 303-328.

House, J. (1996): "Developing Pragmatic Fluency in English as a Foreign Language," Studies in Second Language Acquisition 18, p. 225-252.

House, J. (1997): Translation Quality Assessment: A Model Revisited, Tübingen, Narr.

Hutz, M. (1997): Kontrastive Fachtextlinguistik für den fachbezogenen Fremdsprachenunterricht: Fachzeitschriftenartikel der Psychologie im interlingualen Vergleich, Trier, WVT.

Johns, T. (1998): “Kibbitzer 32," http://web.bham.ac.uk/johnstf/revis032.htm

Kachru, Y. (1983): "Linguistics and Written Discourse in Particular Languages: Contrastive Studies: English and Hindi," Annual Review of Applied Linguistics 3, p. 50-77.

Kaplan, R. B. (1966/1980): "Cultural Thought Patterns in Intercultural Education," Croft, Kenneth (ed.) (1980) Readings on English as a Second Language Cambridge, Winthrop, p. 399-418.

Kreutz, H. and A. Harres (1997): "Some observations on the distribution and function of hedging in German and English academic writing," Duszak, A. (ed.) (1997) Culture and Styles of Academic Discourse, Berlin, Mouton de Gruyter, p. 181-202.

Mauranen, A. (1993): Cultural Differences in Academic Rhetoric: A Textlinguistic Study, Frankfurt, Lang.

Myers, G. (1989): “T he Pragmatics of Politeness in Scientific Articles," Applied Linguistics 10, p. 1-35.

Nash, W. (1980): Designs in Prose, London/New York, Longman.

PöckL, W. (1995): 'Nationalstile in Fachtexten? Vom Tabu- zum Modethema', Fachsprache 17, p. 98-107.

Quillard, G. and G. Akhras (1996): «And/et. Analyse distributionnelle de la conjonction copulative en français et en anglais», Meta 41-3, p. 459-470.

Rounds, P. (1982): Hedging in Written Academic Discourse: Precision and Flexibility, The University of Michigan, Mimeo.

Rousseau, J. and J. Demarty-Warzée (2000): Français de l'avenir et avenir du français, Paris, Didier, PDF version available from www.00h00.com

Sachtleber, S. (1993): 'Textstile in der Wissenschaftssprache', Schröder, H. (ed.) (1993) Fachtextpragmatik, Tübingen, Narr, p. 61-79.

Salager-Meyer, F. (1994): "Hedges and Textual Communicative Function in Medical English Written Discourse," English for Specific Purposes 13, p. 149-169. SChröDer, H. (1988): 'Fachtext, interkulturelle Kommunikation und Aufgaben einer spezialisierten Didaktik/ Methodik des fachbezogenen Fremdsprachenunterrichts', Gnutzmann, Claus (ed.) (1988) Fachbezogener Fremdsprachenunterricht, Tübingen, Narr, p. 107-124. 
Schwanzer, V. (1981): 'Syntaktisch-stilistische Universalia in den wissenschaftlichen Fachsprachen' in Bungarten, T. (ed.) (1981) Wissenschaftssprache. Beiträge zur Methodologie, theoretischen Fundierung und Deskription, München, Fink, p. 213-230.

Siepmann, D. (2001): "Multi-word Discourse Markers in Translation: a Corpus-based Investigation into Restrictors," Lebende Sprachen 3, p. 97-107.

Siepmann, D. (forthcoming): Discourse Markers across Languages, London, Routledge.

Stolze, R. and A. Deppert (1998): 'Übersetzung und Verständlichkeit deutscher und englischer Wissenschaftstexte' Fachsprache 20, p. 116-129.

Trumpr, E. (1998): Kultur- und textsortenspezifische Vertextungsstrategien. Eine kontrastive fachtextlinguistische Untersuchung zum Kommunikationsbereich der Sportwissenschaft: Englisch - Deutsch - Französisch, Tübingen, Narr.

Vinay, J.-P. and J. Darbelnet (1958): Stylistique comparée du français et de l'anglais. Méthode de traduction, Paris, Didier.

Widdowson, H. G. (1979): Aspects of Language Teaching, Oxford, Oxford University Press. 